\title{
On the presence of aluminium in human endometrial tissue and potential factors that may influence it - a pilot study
}

\author{
Piotr Rzymski ${ }^{1}$, Przemysław Niedzielski², Paweł Rzymski³, Barbara Poniedziałek', \\ Katarzyna Tomczyk ${ }^{3}$, Tomasz Opala ${ }^{3}$ \\ ${ }^{1}$ Department of Biology and Environmental Protection, Poznan University of Medical Sciences, Poland \\ 2 Department of Analytical Chemistry, Faculty of Chemistry, Adam Mickiewicz University, Poznań, Poland \\ ${ }^{3}$ Department of Mother's and Child's Health, Gynecologic and Obstetrical University Hospital, Poznan University \\ of Medical Sciences, Poland
}

\begin{abstract}
Introduction. Aluminium (Al), the most ubiquitous metal in the earth crust, has been shown to reveal a potential metalloestrogenic action. Despite an increasing interest in Al exposure in human, there is essentially no information on its status in the reproduction system.

Aim. The present work investigated the content of Al in female endometrial tissue $(n=25)$ and its association with endometrial thickness and histological image, female age, place of living, history of cigarette smoking and diet. Material and methods. The endometrial samples $(n=25)$ were obtained during routine procedures. The Al content was determined using microwave induced nitrogen plasma atomic emission spectrometer. The relationships between metal level and histological image, endometrial thickness, female age, place of living, cigarette smoking and diet were investigated.

Results. The Al was detected in every analysed sample. Its concentrations varied from $0.9-16.0 \mu \mathrm{g} / \mathrm{kg}$ dry tissue. The lowest Al level was found in atrophic endometrium. The metal content in polyposis, hyperplasia and unaltered tissue was comparable. The study failed to find significant association with the metal content and endometrial thickness, female age, place of living, smoking habits and diet.

Conclusion. Human endometrial tissue can contain detectable levels of Al. It, in turn, indicates that endometrium may play a role in systematic accumulation of absorbed Al but also that it may represent an unique route of periodic discharge of this element. Further studies are necessary to elucidate which factors are responsible for the presence of $\mathrm{Al}$ in endometrium and what are the possible consequences of its increased content in this tissue.
\end{abstract}

Keywords: aluminium, endometrium, lesions, bioaccumulation.

\section{Introduction}

Despite a relatively wide interest in metallic elements and their interactions with human body, still little is known as to their status in female reproductive system and potential factors that can influence it. In general, metals constitute an important but broad chemical group of highly essential elements that can support reproduction (e.g. Zn) but also that these reveal certain toxicities (e.g. $\mathrm{Cd}, \mathrm{Pb}$ ), and have been associated with increased risk of infertility [1, 2], pregnancy loss [3], endometrial [4] and uterine cancers as well as endometriosis [5]. Mostly, assessments of metal exposures in humans employ the analytical investigations of blood, hair or urine [6-8]. As long as these samples are generally easy to collect and process, and can reflect the current status of circulating metal content, they may 
not represent a sufficient information on the burden of these elements in particular tissues [9].

As shown in our previous study, the endometrium, the innermost glandular tissue of the uterine cavity, can be a potential target of metal accumulation within the human body [10]. The detected metals included Cd, $\mathrm{Cr}$, $\mathrm{Ni}$ and $\mathrm{Pb}$, which represent an emerging group of potential metalloestrogens, compounds possessing the ability to bind estrogen receptors and give rise to estrogen agonist responses. So far they have been implicated in the aetiology of estrogen-dependent diseases such as cancers of the breast and endometrium as well as endometriosis [11-13]. As endometrial tissue is characterized by the high expression of both estrogen receptors, alpha and beta $[14,15]$, their potential interaction with selected metals is plausible. Interestingly, endometrial tissue with histological lesions was shown to contain higher levels of toxic metals, particularly $\mathrm{Cd}$ [10]. Altogether, the findings of our previous study highlighted the potential usefulness of quantitative analyses of endometrial metal content as an additional indicator of impairments of the menstrual cycle and fertility.

Aluminium (Al), which is the most ubiquitous metal in the earth crust, is not known to play any biological function. Moreover, it has been potentially implicated in induction of neurodegenerative diseases [16] and to act as a metalloestrogen [11]. Generally, Al is poorly absorbed in gastrointestinal tract (in range of $0.1-1.0 \%$ of oral dose) and in healthy subjects almost all of absorbed $\mathrm{Al}$ is most likely excreted readily from the body [17]. The remaining Al is unequally distributed with the highest content found in bones (approx. 41\%), muscles (approx. 40\%) and lungs (approx. 12\%) [18]. The increased accumulation in humans including deposition in brain and toxic effects of Al can, however, occur in patients with renal failure or if the doses largely exceed the excretory capacity [19]. Ingestion with fruit juices or citric acid causes a marked increase in gastrointestinal absorption [20]. The exposure to Al in general population can be high as its compounds are widely used as food additives and cosmetic ingredients, and have medical implications as antacids, phosphate binders, buffered aspirins, vaccines and allergen injections [21]. Moreover, Al exposure has been shown to increase at least 30 -fold over the last 50 years with currently $11 \mathrm{~kg}$ of Al being cast for every human each year [22]. At the same time, there is essentially no information on Al status in human tissues constituting the reproduction system, including endometrium.

The present study was undertaken in order to study the content of $\mathrm{Al}$ in the functional layer (shed during menstruation) of human endometrial tissue obtained from healthy female subjects and these with identified histological lesions. We also aimed to investigate the relation between tissue metal content and endometrial thickness, female age, place of living, history of cigarette smoking and diet. This is the first study to demonstrate that $\mathrm{Al}$ is present in endometrial tissue at the detectable levels and that this tissue can be a potential target of $\mathrm{Al}$ accumulation or a route of elimination of this element through periodic discharge.

\section{Material and methods}

\section{Study group}

Samples of endometrium were obtained from 25 white Caucasian females undergoing diagnostic or therapeutic curettage of the uterine cavity under general anesthesia in the Gynecologic and Obstetrical University Hospital in Poznań, Poland. The causes of intervention were abnormal excessive bleeding, bleeding after menopause or hypertrophy of the endometrium estimated in ultrasound examination (Aloka SSD3500, Japan). All procedures were performed as a routine medical treatment. Endometrial samples were obtained using a surgical stainless steel curettage instrument. During this procedure time of contact of a curettage instrument and sampled tissue did not exceed $1 \mathrm{~s}$. To maintain diagnostic quality, samples were divided using plastic instrument into $0.2 \times 0.2 \times 0.2 \mathrm{~mm}$ pieces for metal content analyses (one sample per female due to limited tissue material) and the rest of the material was sent for routine pathological examination. The tissue samples utilized for metal analyses were first profusely flushed (to remove blood) and then immersed in sterile distilled water (Polpharma, Poland), and placed in cryogenic tubes (Nunc $^{\text {Tm}}$, ThermoScientific, United States) and stored at $-40^{\circ} \mathrm{C}$ prior to determination. None of the studied individuals were exposed to occupational sources of metals. Based on a short questionnaire, the place of living, smoking habits and diet of the investigated females were specified. The study was approved by the local bioethical committee of the Poznan University of Medical Sciences, Poznan, Poland and every patient undersigned the written consent.

\section{Al content analyses}

Tissue samples were handled using plastic instruments with special care taken to avoid any contamination. Thawed tissues were dried in an oven at $40^{\circ} \mathrm{C}$, flushed twice with MilliQ water (Millipore, USA) to ensure the 
removal of blood remnants, dried to a constant weight and then weighed. Complete digestion was performed with suprapure $14 \mathrm{~mol} / \mathrm{L} \mathrm{HNO}_{3}$ (Sigma-Aldrich, Germany) in sealed plastic tubes using an oven $\left(80^{\circ} \mathrm{C}\right)$. The concentration of $\mathrm{Al}$ in the investigated samples was determined at $396.152 \mathrm{~nm}$ by a microwave induced nitrogen plasma atomic emission spectrometer (Agilent, USA) equipped with a nitrogen generator. The determination was performed in triplicate, values were averaged. The calibration was performed using standard analytical solution (Merck, Germany). Prior to the analysis, the detection method was validated as already described [10, 23]. Moreover, a control without any tissue but containing $\mathrm{HNO}_{3}$ was performed in order to exclude the interference of any procedure step on metal content determination - all analyzed elements were below limits of detection. The final concentrations of $\mathrm{Al}$ was given as $\mu \mathrm{g}$ metal per $\mathrm{kg}$ of dry tissue.

\section{Statistical calculations}

The results were analyzed using STATISTICA 10.0 software (StatSoft, U.S.A.). Gaussian distribution was tested with Shapiro-Wilk's test, and because most of the data did not meet this assumption, non-parametric meth- ods were employed. To evaluate differences between two independent groups the Mann-Whitney U test was used. Relations between two datasets were determined with Spearman's rank correlation coefficient. $\mathrm{P}<0.05$ was considered as statistically significant.

\section{Results}

Characteristics of the study group are presented in Table 1 . The Al was detected in every analysed sample at mean $( \pm S D)$ concentration of $5.89( \pm 4.42) \mu \mathrm{g} /$ $\mathrm{kg}$ and $0.90-16.0 \mu \mathrm{g} / \mathrm{kg}$ range. There was no statistical difference in $\mathrm{Al}$ content between groups with recognized lesions and normal histological image. The overall mean $\mathrm{Al}$ concentration in endometrial tissue with particular histological image decreased in the following order: no lesions > polyposis > hyperplasia > atrophy (Figure 1). There was no correlation between metal content and endometrial thickness.

There was no significant relationship between the age of the women and the content of any studied metal. Moreover, females $\leqslant 40$ years old did not differ in endometrial metal contents from females $>40$ years old (Table 2).

Table 1. Characteristics of the study group

\begin{tabular}{|c|c|}
\hline Age (years) (mean $\pm S D)$ & $45.0 \pm 13.6$ \\
\hline Endometrial thickness $(\mathrm{mm})($ mean $\pm \mathrm{SD})$ & $10.5 \pm 3.9$ \\
\hline $\begin{array}{l}\text { Histological image } \\
\text { No lesions (n) } \\
\text { Lesions (n) } \\
\text { - endometrial simple hyperplasia (n) } \\
\text { - endometrial polyposis (n) } \\
\text { - atrophic endometrium (n) }\end{array}$ & $\begin{array}{l}14 \\
11 \\
4 \\
5 \\
2\end{array}$ \\
\hline $\begin{array}{l}\text { Place of living } \\
\leqslant 25 \text { thousand residents }(n) \\
25-100 \text { thousand residents }(n) \\
\geqslant 100 \text { thousand residents }(n)\end{array}$ & $\begin{array}{c}3 \\
13 \\
9\end{array}$ \\
\hline $\begin{array}{l}\text { Diet (frequency of product consumption) } \\
\text { - Fish very rarely (n) } \\
\text { - Fish rarely (n) } \\
\text { - Fish moderate (n) } \\
\text { - Meat rarely (n) } \\
\text { - Meat moderate }(n) \\
\text { - Meat often }(n) \\
\text { - Meat very often (n) } \\
\text { - Fruits moderate (n) } \\
\text { - Fruits often (n) } \\
\text { - Fruits very often (n) }\end{array}$ & $\begin{array}{c}9 \\
10 \\
5 \\
2 \\
7 \\
12 \\
3 \\
1 \\
13 \\
10 \\
\end{array}$ \\
\hline $\begin{array}{l}\text { Smoking history } \\
\text { Non-smokers } \\
\text { Current smokers } \\
\text { Former smokers: } \\
\text { - Years of smoking (mean } \pm \text { SD) } \\
\text { - Smoking frequency range (cigarettes per day) (mean } \pm \text { SD) }\end{array}$ & $\begin{array}{c}12 \\
3 \\
10 \\
12.4 \pm 12.5 \\
9.6 \pm 7.4\end{array}$ \\
\hline
\end{tabular}




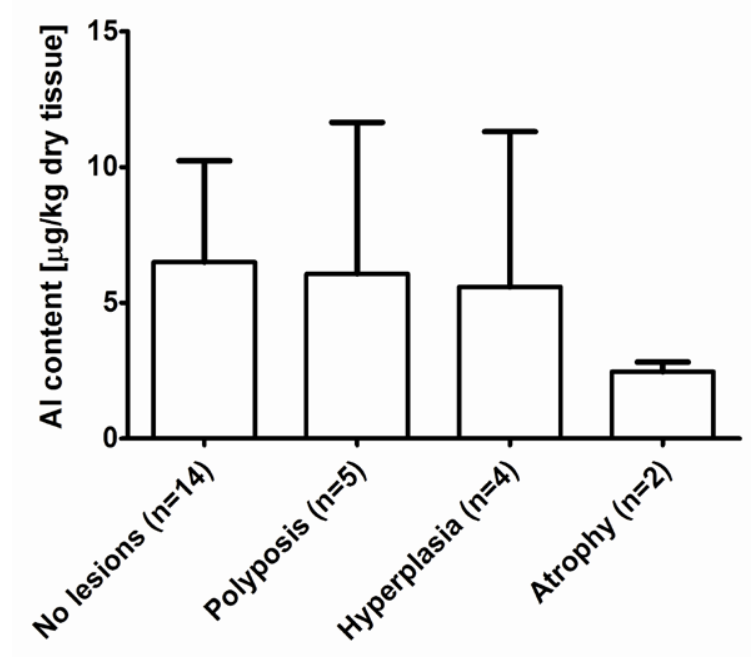

Figure 1. Level of Al content in different histological patterns of endometrial tissue. Columns represent mean, the bars represent standard deviation

No statistically significant correlations with years of smoking or number of cigarettes smoked per day and the metal content were found. Moreover, current and former smokers did not differ significantly in the metal content from non-smoking females. Nevertheless, an increased mean Al content was observed in female with smoking history (Table 2).

The lowest Al content was found in endometrium collected from female inhabiting areas $\leqslant 25$ thousand residents (Table 2) although a large disproportion in the number of individuals of each group excluded the possibility for representative statistical comparison and the differences in metal content between inhabitants of small, middle and large residence areas was insignificant. Moreover, there was no significant correlation between the exact number of residents and Al content.

The frequency of fruit, fish and meat consumption was also not found to be associated with Al content; no clear pattern for any of considered food product was demonstrated (Table 2).

\section{Discussion}

To the best of our knowledge, this is the first study to investigate and determine the Al content in endometrial tissue. This was mostly possible due to the use of highly sensitive MIP-OES technique although due to the preliminary nature of this research, relatively low sample size and several study limitations, one should treat the results cautiously. Firstly, the study lacks a real control group as due to ethical reasons we were unable to obtain samples from subjects having no medical indication for this procedure. The group of females with tissue not found to be histologically altered can be, however, treated as a provisional control. Secondly, the access to tissue sample for metal content analyses was largely limited and we were unable to collect more than one piece of tissue from each female. Such possibility would allow studying the homogeneity of $\mathrm{Al}$

Table 2. Mean $( \pm S D)$ content of $\mathrm{Al}(\mu \mathrm{k} / \mathrm{kg}$ dry tissue) in human endometrium in different female groups (no statistically significant differences were found)

\begin{tabular}{|c|c|c|}
\hline Group & & Al content \\
\hline \multirow{2}{*}{ Age (years) } & Female $<40(n=11)$ & $6.9( \pm 4.7)$ \\
\hline & Female $>40(n=14)$ & $5.0( \pm 4.2)$ \\
\hline \multirow{4}{*}{ Smoking habit } & Non-smokers $(n=12)$ & $4.8( \pm 2.5)$ \\
\hline & Current smokers $(n=3)$ & $5.4( \pm 5.0)$ \\
\hline & Former smokers $(n=10)$ & $7.1( \pm 5.7)$ \\
\hline & Current + current smokers $(n=13)$ & $6.7( \pm 5.4)$ \\
\hline \multirow{3}{*}{ Place of living (number of residents) } & $<25.000(n=3)$ & $2.1( \pm 0.8)$ \\
\hline & $25.000-100.000(n=13)$ & $6.2( \pm 3.5)$ \\
\hline & $100.000(n=9)$ & $6.8( \pm 5.8)$ \\
\hline \multirow{3}{*}{ Diet - fish consumption } & Very rarely $(n=9)$ & $7.2( \pm 5.3)$ \\
\hline & Rarely $(n=10)$ & $5.1( \pm 3.8)$ \\
\hline & Moderate $(n=5)$ & $4.1( \pm 5.3)$ \\
\hline \multirow{4}{*}{ Diet - meat consumption } & Rarely $(n=2)$ & $10.2( \pm 8.3)$ \\
\hline & Moderate $(n=7)$ & $4.4( \pm 2.9)$ \\
\hline & Often $(n=12)$ & $5.1( \pm 3.9)$ \\
\hline & Very often $(n=3)$ & $8.0( \pm 6.3)$ \\
\hline \multirow{3}{*}{ Diet - fruits consumption } & Moderate $(n=1)$ & 5.8 \\
\hline & Often $(n=13)$ & $5.8( \pm 4.8)$ \\
\hline & Very often $(n=10)$ & $5.5( \pm 4.3)$ \\
\hline
\end{tabular}


content within the endometrial layer. Thirdly, it was impossible to use any other instrument to collect samples than curettage instrument made of stainless steel. Moreover, due to small sample size, it was not possible to cut the piece sufficient for metal analyses using the non-metal instrument. It is, however, unlikely that steel could introduce $\mathrm{Al}$ into the tissues during specimen collection and further, its contact time was very short and relatively equal for each patient. In Table 3 we have provided the list of detailed steps which can help avoid metal contamination during human tissue processing in future research.

The $\mathrm{Al}$ content found in the present study was shown to vary between investigated females but did not exceed $16.0 \mu \mathrm{g} / \mathrm{kg}$. Compared to other metals investigated previously in human endometrium, $\mathrm{Al}$ occurred at moderate level - lower than $\mathrm{Cr}, \mathrm{Pb}$ and Zn but higher than $\mathrm{Ni}$ and $\mathrm{Mn}[10,24,25]$. According to the current state of knowledge, the hematogenous route is most likely the main source of various metals for this tissue [25]. Since the functional layer of endometrium is shed during menstrual cycle, it can represent not only a target of $\mathrm{Al}$ accumulation but, additionally to defecation and urine secretion, a route of periodic discharge of contaminants circulating in the bloodstream. Further studies are necessary to elucidate these issues and should involve comparison of metal content between secretory and proliferation phases. As found, other metals, $\mathrm{Zn}$ and $\mathrm{Cu}$ tend to increase its content in endometrial tissue during menstrual cycle reaching the lowest levels during ovulation time and the highest at late secretory phase [26]. However in general the present study did not disclose any difference in $\mathrm{Al}$ content between lesioned and normal tissue, the atrophic endometrium revealed the lowest metal level. Because the size of each group of histological image (normal, hyperplasia, polyposis and atrophy) was small, further research is necessary to elucidate the accumulation of $\mathrm{Al}$ in different endometrial lesions including malignancy.

It is unknown whether the increased presence of $\mathrm{Al}$ in endometrial tissue can lead to any specific responses or alterations. Al is not known to play any biological role in living organisms and further, its excess can lead, at the cellular level, to a significant increase in reactive oxygen species and induce oxidative damage $[27,28]$. A few recent studies have also revealed that $\mathrm{Al}$ can induce some alterations in female reproduction system. In rodents, the oral administration of $\mathrm{Al}$ has led to significant decrease of serum content of estrogen, progestogen, testosterone, follicle-stimulating hormone, and luteinizing hormone [29]. Moreover, the metalloestrogenic action of Al has been demonstrated in MCF7 human breast cancer cells, in which $\mathrm{Al}$ in form of Al chloride or chlorhydrate has been shown to displace $[3 \mathrm{H}]$-estradiol from cytosolic estrogen receptor (ER) [30]. The possible adverse effects of Al on endometrium would require further studies, for example relationship between metal content and ER expression in endometrial tissue or in vitro experiments using the human endometrial cell line (e.g. T HESCs).

Further studies are necessary to assess the relationship (if any) between serum and urine Al content and this found in tissues of reproduction system and to fully elucidate the potential factors that can influence it. The present study did not disclose any significant relationships between metal content and endometrial thickness, occurrence of lesions, female age, diet, place of living smoking habits. As diet appears to be a main source of $\mathrm{Al}$ exposure in humans, there is a need to conduct studies on larger group of participants, possibly representing different dietary habits and varying in the daily intake of this metal. The decreased mean content of $\mathrm{Al}$ in atrophic tissue and increased in females with smoking history requires further research involving larger group of participants.

Table 3. Recommendations for metal analyses in human tissue samples which undergo complete digestion

\begin{tabular}{|c|c|}
\hline Collection & $\begin{array}{l}\text { If possible use only plastic or other metal-free (e.g. made of zirconium carbide) instruments. Otherwise, use stainless-steel instruments } \\
\text { and avoid longer contact with tissue sample. }\end{array}$ \\
\hline Processing & $\begin{array}{l}\text { Use ultra-pure or at least double distilled water to get rid of blood and blood remnants from tissue sample. } \\
\text { Flush the tissue profusely at least } 2-3 \text { times. } \\
\text { If stainless steel was used during collection and the sample is large enough, use metal-free instrument to cut the unaffected piece. }\end{array}$ \\
\hline Handling & $\begin{array}{l}\text { Use only plastic instruments to handle the tissue sample. } \\
\text { Avoid any contact with metal surfaces. }\end{array}$ \\
\hline Digestion & $\begin{array}{l}\text { Use only suprapure acids. } \\
\text { Test the metal content in the solution used to digest tissue samples to exclude potential interference with results. }\end{array}$ \\
\hline Storage & The digested samples should be stored no longer than 2 months prior to analyses. \\
\hline Analyses & $\begin{array}{l}\text { Use standard solutions for instrument calibration. } \\
\text { Use standard reference material appropriate for the analysed tissue (e.g. bovine liver). }\end{array}$ \\
\hline
\end{tabular}




\section{Conclusion}

The human functional layer of human endometrial tissue contains various concentrations of Al. The potential factors which can influence the content of this metal remain unknown. Further research is necessary to elucidate the relationship between specific endometrial lesions and metal content. Moreover, the potential effects of $\mathrm{Al}$ presence in endometrium should be addressed. It can be suggested that accumulation of $\mathrm{Al}$ in functional layer of endometrial tissue may represent an unique and so far unknown route of periodic discharge of toxic contaminants such as metals from female body.

\section{Acknowledgements}

We are grateful to all the patients for their participation in this study. We wish to express sincere thanks to Ms. Teresa Poniedziałek (Gynecologic and Obstetrical University Hospital in Poznań, Poland) for her help in processing tissue samples and to Professor Jan Milecki from the Faculty of Chemistry of Adam Mickiewicz University in Poznan for the possibility to use the MIP-OES instrument.

\section{Conflict of interest statement}

The authors declare that there is no conflict of interest in the authorship or publication of contribution.

\section{Funding sources}

This study was partially supported by funds from the Young Scientists Project of Poznan University of Medical Sciences (No. 502-14-04412525-41170).

\section{References}

1. Chang SH, Cheng BH, Lee SL, Chuang HY, Yang CY, Sung FC, Wu TN. Low blood lead concentration in association with infertility in women. Environ Res. 2006;101: 380-386.

2. Kim D, Bloom MS, Parsons PJ, Fitzgerald EF, Bell EM, Steuerwald AJ, Fujimoto VY. A pilot study of seafood consumption and exposure to mercury, lead, cadmium and arsenic among infertile couples undergoing in vitro fertilization (IVF). Environ Toxicol Pharmacol. 2013;36: 30-34.

3. Ajayi OO, Charles-Davies MA, Arinola OG. Progesterone, selected heavy metals and micronutrients in pregnant Nigerian women with a history of recurrent spontaneous abortion. Afr Health Sci. 2012;12:153-159.

4. Akesson A, Julin B, Wolk A. Long-term dietary cadmium intake and postmenopausal endometrial cancer incidence: a population-based prospective cohort study. Cancer Res. 2008;68:6435-6441.

5. Jackson LW, Zullo MD, Goldberg JM. The association between heavy metals, endometriosis and uterine myomas among premenopausal women: National Health and Nutrition Examination Survey 1999-2002. Hum Reprod. 2008;23:679-687.
6. Lee JW, Lee CK, Moon CS, Choi IJ, Lee KJ, Yi SM, Jang BK, Yoon BJ, Kim DS, Peak D, Sul D, Oh E, Im H, Kang HS, Kim J, Lee JT, Kim K, Park KL, Ahn R, Park SH, Kim SC, Park $\mathrm{CH}$, Lee JH. Korea National Survey for Environmental Pollutants in the Human Body 2008: heavy metals in the blood or urine of the Korean population. Int J Hyg Environ Health. 2012;215:449-457.

7. Chanpiwat P, Lee BT, Kim KW, Sthiannopkao S. Human health risk assessment for ingestion exposure to groundwater contaminated by naturally occurring mixtures of toxic heavy metals in the Lao PDR. Environ Monit Assess. 2014;186:4905-4923.

8. Interdonato $M$, Bitto A, Pizzino G, Irrera N, Pallio G, Mecchio A, Cuspilici A, Minutoli L, Altavilla D, Squadrito F. Levels of heavy metals in adolescents living in the industrialised area of Milazzo-valle del Mela (Northern Sicily). J Environ Public Health. 2014. DOI: 10.1155/2014/326845

9. Gerhardsson L, Englyst V, Lundström NG, Sandberg S, Nordberg G. Cadmium, copper and zinc in tissues of deceased copper smelter workers. J Trace Elem Med Biol. 2002;16:261-266.

10. Rzymski P, Rzymski P, Tomczyk K, Niedzielski P, Jakubowski K, Poniedziałek B, Opala T. Metal status in human endometrium: relation to cigarette smoking and histological lesions. Environ Res. 2014;132:328-333.

11. Darbre PD. Metalloestrogens: an emerging class of inorganic xenoestrogens with potential to add to the oestrogenic burden of the human breast. J Appl Toxicol. 2006;26:191-197.

12. Hartwig A. Mechanisms in cadmium-induced carcinogenicity: recent insights. Biometals. 2010;23:951-960.

13. Silva N, Peiris-John R, Wickremasinghe R, Senanayake H, Sathiakumar N. Cadmium a metalloestrogen: are we convinced? J Appl Toxicol. 2012;32:318-332.

14. Jones RK, Bulmer JN, Searle RE. Immunohistochemical characterization of proliferation, oestrogen receptor and progesterone receptor expression in endometriosis: comparison of eutopic and ectopic endometrium with normal cycling endometrium. Human Reprod. 1995;10: 3272-3279.

15. Lecce G, Meduri G, Ancelin M, Bergeron C, Perrot-Applanat $M$. Presence of estrogen receptor beta in the human endometrium through the cycle: expression in glandular, stromal, and vascular cells. J Clin Endocrinol Metab. 2001;86:1379-1386.

16. Wu Z, Du Y, Xue H, Wu Y, Zhou B. Aluminum induces neurodegeneration and its toxicity arises from increased iron accumulation and reactive oxygen species (ROS) production. Neurobiol Aging. 2012;33(1):199.e1-e12.

17. Taylor GA, Moore PB, Ferrier IN, Tyrer SP, Edwardson JA. Gastrointestinal absorption of aluminium and citrate in man. J Inorg Biochem. 1998;69:165-169.

18. De Broe ME, Van de Vyver FL, Silva FJ, D'Hase P, Verbueken $\mathrm{H}$, Measuring aluminium in serum and tissues. Overview and perspectives. Nefrologia. 1986;6(Suppl. 1): 41-46.

19. Yokel RA, McNamara PJ. Aluminium toxicokinetics: an updated minireview. Pharmacol Toxicol. 2001;88:159-167.

20. Venturini-Soriano M, Berthon G. Aluminum speciation studies in biological fluids. Part 7. A quantitative investigation of aluminum(III)-malate complex equilibria and 
their potential implications for aluminum metabolism and toxicity. J Inorg Biochem. 2001;85:143-154.

21. Exley C. Does antiperspirant use increase the risk of aluminium-related disease, including Alzheimer's disease? Mol Med Today. 1998;4:107-109.

22. Exley C. Human exposure to aluminium. Environ Sci Process Impacts. 2013;15:1807-1816.

23. Niedzielski P, Kozak L, Wachelka M, Jakubowski K, Wybieralska J. The microwave induced plasma with optical emission spectrometry (MIP-OES) in 23 elements determination in geological samples. Talanta. 2014. DOI: 10.1016/j.talanta.2014.10.009

24. Yaman M, Kaya G, Simsek M. vComparison of trace element concentrations in cancerous and noncancerous human endometrial and ovary tissues. Int J Gynecol Cancer. 2007;17:220-228.

25. Silva N, Senanayake H, Peiris-John R, Wickremasinghe $\mathrm{R}$, Sathiakumar N, Waduge V. Presence of metalloestrogens in ectopic endometrial tissue. J Pharm Biomed Sci. 2012;24:1-5.

26. Hagenfeldt K, Plantin LO, Diczfalusy E. Trace elements in the human endometrium. 2. Zinc, copper and manganese levels in the endometrium, cervical mucus and plasma. Acta Endocrinol (Copenhagen). 1973;72:115-126.

27. Kumar V, Bal A, Gill KD. Susceptibility of mitochondrial superoxide dismutase to aluminium induced oxidative damage. Toxicology. 2009;255:117-123.
28. Mannello F, Ligi D, Canale M. Aluminium, carbonyls and cytokines in human nipple aspirate fluids: Possible relationship between inflammation, oxidative stress and breast cancer microenvironment. J Inorg Biochem. 2013;128:250-256.

29. Wang N, She Y, Zhu Y, Zhao H, Shao B, Sun H, Hu C, Li Y. Effects of subchronic aluminum exposure on the reproductive function in female rats. Biol Trace Elem Res. 2012;14: 382-387.

30. Darbre PD. Aluminium, antiperspirants and breast cancer. J Inorg Biochem. 2005;99:1912-1919.

Acceptance for editing: 2014-12-10 Acceptance for publication: 2014-12-31

\section{Correspondence address:} Piotr Rzymski

Department of Biology and Environmental Protection Poznan University of Medical Sciences 8 Rokietnicka Street, 60-806 Poznań, Poland phone/fax: +48 618549178 email: rzymskipiotr@ump.edu.pl 